Zavadska Diana,

Dr. Sc. (Econ.), Assoc. Prof., Department of Banking, Odessa National Economic University, Odessa, Ukraine ORCID ID: http://orcid.org/0000-0003-2950-554X zavadska.diana@ukr.net

\title{
IMPROVEMENT OF THE ASSESSMENT METHODOLOGY OF LENDING POTENTIAL OF UKRAINE'S BANKS
}

Object of study. The object of the study are the processes of forming the lending potential of the banking system. One of the most problematic areas is the lack of comprehensive research on the formation of scientific and methodological approaches to determine and assess the lending potential of the bank. The research has emphasized the need to solve problems of innovative development of Ukraine's economy.

Methodology. The information base of the research is the regulations of the National Bank of Ukraine, official analytical and statistical data of organizations and the results of scientific research of leading economists. The following methods have been used: abstraction and morphological analysis (specifying the definition of "lending potential of the bank"); system-structural, induction, deduction, coefficient (in the development of scientific and methodological approach and quantitative assessment of the lending potential of banks); comparative analysis and logical generalization, which allowed to determine the prerequisites for the development of bank lending to the economy and their role in financing investment projects in Ukraine.

Results. The necessity of developing measures for the rational use of lending potential, including the results of the calculations, the insignificant lending potential of Ukrainian banks in the period 2014-2017 which has been growing rapidly since 2018 has been revealed. It has been proved that the profitability of non-financial corporations gradually increases during the study period, which has a positive effect on their workload regarding debt service. These trends create the preconditions for the development of bank lending to the real sector of the economy and households. It has been noted that only $6 \%$ of innovative projects are financed with the use of bank loans.

Scientific novelty. The article has proposed to deepen the methodological approaches to the disclosure of the content and quantitative assessment of the lending potential of banks. The information obtained is the basis for determining the possibilities of creating a positive lending potential of banks. A prerequisite for the effective use of potential is the availability of solvent borrowers and the absence of excessive debt burden.

Theoretical and (or) practical significance. The use of the proposed methodology allows to assess the prerequisites for the development of bank lending and the implementation of a positive contribution of the banking system to economic growth.

Keywords: bank, lending potential, assessment, scientific approaches, prerequisites of credit development, borrower, debt load, project financing, innovative development of economy.

\author{
Завадська Діана, \\ д.е.н., дочент кафедри банківської справи, \\ Одеський начіональний економічний університет, м. Одеса, Украӥна \\ ORCID ID: http://orcid.org/0000-0003-2950-554X \\ zavadska.diana@ukr.net
}

\section{УДОСКОНАЛЕННЯ МЕТОДОЛОГІЇ ОЦІНКИ КРЕДИТНОГО ПОТЕНЦІАЛУ БАНКІВ УКРАЇНИ}

Об’єкт дослідження. Об'єктом дослідження є процеси формування кредитного потенціалу банківської системи. Одним з найбільш проблемних місць $є$ відсутність комплексних досліджень щодо формування науково-методичних підходів до визначення й оцінки кредитного потенціалу банку, наявність якого обумовлена необхідністю вирішення завдань забезпечення інноваційного розвитку економіки України.

Методологія. Інформаційною базою дослідження є нормативно-правові акти Національного банку України, офіційні аналітичні і статистичні дані організацій та результати наукових досліджень провідних вчених-економістів. Використані такі методи: абстрагування та морфологічний аналіз (при уточненні дефініції “кредитний потенціал банку”); системно-структурний, індукція, дедукція, коефіцієнтний (при розробці науково-методичного підходу та кількісної оцінки кредитного потенціалу банків); компаративний аналіз та логічного узагальнення, що дозволило визначити передумови розвитку кредитування банками економіки та їх роль у фінансуванні інвестиційних проектів в Україні.

Результати. Обгрунтовано необхідність розробки заходів щодо раціонального використання кредитного потенціалу в т.ч. для фінансування інноваційної діяльності. За результатами проведених розрахунків виявлено незначний кредитний потенціал банків України в період 2014-2017 рр., який стрімко зростає, починаючи 3 2018 р. Доведено, що прибутковість нефінансових корпорацій поступово зростає протягом досліджуваного періоду, що позитивно впливає на їхнє навантаження стосовно обслуговування боргу. Ці тенденції створюють 
передумови розвитку кредитування банками реального сектору економіки та домогосподарств. Зазначено, що 3 використанням банківських кредитів фінансується лише 6\% інноваційних проектів.

Наукова новизна. У статті запропоновано поглиблення методологічних підходів до розкриття змісту та кількісної оцінки кредитного потенціалу банків. Отримана інформація є основою для визначення можливостей створення позитивного кредитного потенціалу банків. Передумовою ефективного використання потенціалу $\epsilon$ наявність платоспроможних позичальників та відсутність у них надмірного боргового навантаження.

Теоретична та (або) практична значущість. Використання запропонованої методології дозволяє оцінити наявність передумов розвитку банківського кредитування та здійснення позитивного внеску банківської системи в економічне зростання.

Ключові слова: банк, кредитний потенціал, оцінка, наукові підходи, передумови розвитку кредитування, позичальник, боргове навантаження, проектне фінансування, інноваційний розвиток економіки.

Завадская Диана,

д.э.н., доиент кафедры банковского дела, Одесский национальный экономический университет, Одесса, Украина ORCID ID: http://orcid.org/0000-0003-2950-554X zavadska.diana@ukr.net

\section{СОВЕРШЕНСТВОВАНИЕ МЕТОДОЛОГИИ ОЦЕНКИ КРЕДИТНОГО ПОТЕНЦИАЛА БАНКОВ УКРАИНЫ}

Объект исследования. Объектом исследования являются процессы формирования кредитного потенциала банковской системы. Одним из самых проблемных мест является отсутствие комплексных исследований по формированию научно-методических подходов к определению и оценке кредитного потенциала банка, наличие которого обусловлено необходимостью решения задач обеспечения инновационного развития экономики Украины.

Методология. Информационной базой исследования являются нормативно-правовые акты Национального банка Украины, официальные аналитические и статистические данные организаций и результаты научных исследований ведущих ученых-экономистов. Использованы следующие методы: абстрагирование и морфологический анализ (при уточнении дефиниции “кредитный потенциал банка”); системно-структурный, индукция, дедукция, коэффициентный (при разработке научно-методического подхода и количественной оценки кредитного потенциала банков); компаративный анализ и логического обобщения, что позволило определить предпосылки развития кредитования банками экономики и их роль в финансировании инвестиционных проектов в Украине.

Результаты. Обоснована необходимость разработки мероприятий, направленных на рациональное использование кредитного потенциала, в т.ч. для финансирования инновационной деятельности. По результатам проведенных расчетов выявлен незначительный кредитный потенциал банков Украины в период 2014-2017 гг., который имеет тенденцию к стремительному росту начиная с 2018 г. Доказано, что доходность нефинансовых корпораций постепенно возрастает в течение исследуемого периода, что положительно влияет на их нагрузку относительно обслуживания долга. Такая ситуация создает предпосылки развития кредитования банками реального сектора экономики и домохозяйств. Отмечено, что с использованием банковских кредитов финансируется лишь 6\% инновационных проектов.

Научная новизна. В статье предложено углубление методологических подходов к раскрытию содержания и количественной оценки кредитного потенциала банков. Полученная информация является основой для определения возможностей создания положительного кредитного потенциала банков. Предпосылкой эффективного использования потенциала является наличие платежеспособных заемщиков и отсутствие в них чрезмерного долговой нагрузки.

Теоретическая и (или) практическая значимость. Использование предлагаемой методологии позволяет оценить наличие предпосылок развития банковского кредитования и осуществления позитивного вклада банковской системы в экономический рост.

Ключевые слова: банк, кредитный потенциал, оценка, научные подходы, предпосылки развития кредитования, заемщик, долговая нагрузка, проектное финансирование, инновационное развитие экономики.

\section{DOI: 10.32680/2409-9260-2020-1-2-274-275-10-27}

\section{Statement of the problem in general.}

The development of the innovative potential of economy requires the necessary financial and lending security. Due to the deficit of budget resources, the issue of involving banks in the support system for the innovation sector of economy, one of the functions of which is to promote economic development, becomes relevant. However, it should be noted that there are a number of factors that constrain the participation of the banking segment in financing innovative projects. First of all, among such factors it is worth noting the 
following: increased risk of lending to innovative projects; availability of banks' resources (lending potential) for the development of lending, including innovation; opportunities for borrowers to attract additional resources, determined by the level of their debt load. All this determines the importance of assessing the lending potential of banks and the level of debt load of the non-financial sector of economy for further development of measures aimed at forming effective forms of integration of banks and the state to ensure innovative development of Ukraine's economy.

\section{Object of research and analysis of existing solutions to problems.}

The object of the study are the processes of forming the lending potential of the banking system. One of the most problematic areas is the lack of comprehensive research on the formation of scientific and methodological approaches to determine and assess the lending potential of the bank. The research has emphasized the need to solve problems of innovative development of Ukraine's economy.

In order to form recommendations for creating conditions for achieving the tasks of ensuring the innovative development of Ukraine's economy, the following issues were studied: determining the content of the term "lending potential of the bank"; study of the impact of excess liquidity reserves on the growth of bank loans; determination of factors influencing the structure and dynamics of the bank's loan portfolio; the need to maintain a balance between the volume of loans and the solvency of customers.

Thus, according to scientists [1, p. 95], "lending potential should determine the economically justified limits of the use of mobilized in the bank sources of funds for lending and other operations; and on the other hand, the bank's lending potential reflects the amount of funds mobilized in the bank minus the total liquidity reserve".

In scientific work [2, p. 63] it is proved that the concept of "lending potential" includes sufficient availability of credit resources of the bank; the minimum allowable value of credit risks and an acceptable assessment of the borrower's solvency.

According to the source [3, p. 101], "every commercial bank seeks a minimum reserve of liquid assets and ensures maximum lending potential, level of compulsory reserves established by the Central Bank, the total amounts and structure of liabilities by maturity".

It is interesting to study the activities of the US banking holding companies [4], which shows that large banks, with high loan growth rates, a significant share of customer funds in their liabilities and which form liquidity reserves through deposits, are more prone to balanced risk-taking policies (they have a small percentage of non-performing loans, NLP). They rather reduce the activity of providing new loans due to the need, firstly, of compliance with mandatory economic capital and liquidity standards, and secondly, through the ability to raise funds in international capital markets and, thirdly, they are interested in placing available funds (excess liquidity reserves) in non-traditional and more complex activities (the so-called "creationtransfer" activity, instead of "creation-maintenance").

At the same time in scientific work [5, p. 28-33], according to the study of more than 2054 banks in 117 developed and developing countries during 2000-2016, it is noted that tougher regulatory policy - the introduction of Basel III - strengthening the capitalization requirements for banks and the need to comply with the indicator for short-term liquidity (stock of high quality liquid assets, LCR), has a direct correlation with the growth of new loans. It is emphasized that capital has a significant positive effect on lending only if banks already maintain a sufficient amount of liquid assets (have the liquidity buffer). However, this situation takes place only in large banks.

As for liquidity indicators, they have a positive effect on lending to the US banks, while for large European banks the success of this relationship depends on the type of lending [5, p. 29]. It is proved that the higher the bank's ability to diversify risks for different types of investments, the higher its ability to protect itself from potential losses and the higher the probability of granting a new loan.

Article [6] emphasizes the importance of bank lending as a source of financing for innovative companies in the UK. Experts determined that the banks' difficulties associated with the formation of a buffer stock of liquidity, particularly during the crisis of 2008 and 2011, negatively affected the innovative activities of companies. The cessation of loans for the development of innovative activities of small and medium enterprises has led to both a reduction in the number of patents and a reduction in their technological value, originality and quality. It was also found that the specialization of banks in the direction of financing innovation mitigates the impact of the above problems on innovations.

In the study [7, p. 140] scientists, considering the problem of capital formation, liquidity reserves and bank lending in countries with economies in transition, proved that banks with a larger liquidity reserve are likely to increase lending. This is due to the fact that investors prefer to keep funds in the form of deposits instead of making direct investments due to the presence of economic risk. 
The authors also emphasize that banks with excess (unused) liquidity reserve provide liquidity to firms through the lending channel [7, p. 142]. These firms are called dependent on banks, as they are unable to raise funds on capital markets. However, they are the engines of economic activity and contribute to higher economic growth.

According to the study [8], “... support for a high level of borrower activity is of great importance for the bank. Attracting new borrowers is based on data from the analysis of the lending potential of the market, which reflects the possible debt load. Further work is related to the attraction of clients and non-clients of the bank, who are able to deal with this debt load and offering them lending products".

The author also singles out such factors influencing the dynamics and structure of the bank's loan portfolio as development of the system of financing various investment projects; phase of the macroeconomic development cycle; instruments of state monetary regulation (refinancing rate, mandatory reserve ratio, etc.).

Thus, the issue of determining the ability of a banking institution to develop lending processes, the amount of funds required, the formation of mandatory reserves of liquidity and capital, taking into account the demand for credit resources and promising areas of financing is a matter of debate and high importance. Therefore, one of the main solutions to the problems of management process for active participation of bank loans as a source of funding for innovative development of economy is the formation of assessment methodologies of bank lending potential.

\section{Selecting previously unsolved parts of the overall problem.}

Most scientific papers are devoted to defining the economic content and factors of lending potential of the bank. Scientists have studied the problems of forming the required reserves, ensuring the interests of owners, creditors and the state at the expense of available resources.

While acknowledging the achievements of scientists, it should be noted that the improvement of approaches to determine lending capacity of individual banks and the banking system, that are measured by excess reserves and provide the basis for expanding the size of innovation loans, remain insufficiently studied. In particular, theoretical and practical issues of creating the preconditions for the effective use of lending potential need in-depth development, including financing the innovative development of Ukraine's economy.

\section{Formulation of purpose of the article and research objectives.}

The purpose of the article is to substantiate the methodology for assessing the lending potential of Ukrainian banks as a basis for determining the prerequisites for financing innovative development. Achieving the goal of the study requires solving the following tasks:

1. Summarize current achievements in determining and calculating the lending potential of individual banks and the banking system as a whole.

2. Compare the available lending potential of the banking system of Ukraine and the debt load of real sector of economy.

3. Define the development level of the banking segment of project finance market in Ukraine.

4. Develop recommendations for involving banks in financing the innovative needs for economic development.

\section{results.}

Presentation of the main research material with a full justification of the obtained scientific

In general, researchers define lending potential as the ability of banks to invest previously obtained resources, which depends on a number of factors. At the same time, interpretations differ, firstly, by the factors of lending potential and, secondly, the understanding of the content of potential as the volume of all attracted resources minus liquidity reserves or only as the volume of excess (unused) liquidity reserves.

Understanding the methodology as a system of ways to organize and form theoretical and practical activities, we can conclude that the methodology for assessing the lending potential of banks is formed on the basis of systematization of existing knowledge and creating new knowledge about the subject and object of research and its logic. Given the etymology of the concept of "potential" as a stock, resources, "that can be used in any industry, site, area" and "hidden ability that may appear under certain conditions" [9], we consider that most consistent essence of determining the lending potential of the bank is the one which is based on the concept of excess reserves and possible growth of the loan portfolio.

Thus, the concept of lending potential is determined by economic content and factors. On this basis, we propose to define the lending potential as the amount of bank funds that can be used to provide new loans 
to households and non-financial corporations, and will ensure that banks make a positive contribution to economic growth. Factors in the formation of the lending potential of banks are the availability of resources of the required amounts and terms; acceptable level of risks and adequacy of equity to absorb them; profit as a factor in increasing resources. It should be noted that the above factors determine the possibility of creating a positive lending potential of banks; at the same time, the prerequisite for the effective use of potential, including the financing of innovative development, is the availability of solvent borrowers and the absence of excessive debt load.

According to the scientific understanding, we believe that approaches to calculating the lending potential of individual banks and the banking system as a whole should be based on the excess resources available in banks. Excess resources or lending potential arise in case of excess of liquidity ratios $\left(P_{l, i}\right)$ and capital $\left(P_{c, i}\right)$ above the minimum set value:

$$
P_{l, i}=F R_{l, i}-N R_{l, i}
$$

where $\mathrm{P}_{1, \mathrm{i}}$ - is the potential formed due to excess liquidity reserves; $F R_{l, i}-$ the actual level of liquidity reserves of the bank $i$ and; $N R_{l, i}$ - regulatory level of the bank $i$ 's liquidity reserves.

$$
N R_{l, i}=L_{i} \times N L
$$

where $L_{i}$ - the amount of liabilities of the bank $i ; N L$ - liquidity ratios (until 01.01 .2019 - the ratio of instant liquidity (H4) and short-term liquidity (H5), starting from 01.01.2019 - the level of liquidity coverage (LCR)) [10].

According to formula 1, it is possible to state the availability of excess liquidity reserves and, accordingly, the lending potential for new loans in case of excess liquidity reserves above the regulatory level.

Similarly, the lending potential is calculated in accordance with the capital ratio:

$$
P_{c, i}=N R W A_{i}-F R W A_{i},
$$

where $\mathrm{P}_{c, i}$ - the potential that is formed in the case of sufficient (surplus) equity; $F R W A_{i}$ - the actual amount of risk-weighted assets of the bank $i ; N R W A_{i}$ - regulatory volume of weighted assets.

The regulatory volume of weighted assets is their maximum possible value in the case of compliance with the minimum level of capital adequacy:

$$
N R W A_{i}=\mathrm{C}_{i} \div C A R_{N},
$$

where $\mathrm{C}_{i}$ - the capital of the bank $i ; C A R_{N}$ - regulatory capital adequacy ratio (the study used a value of $12 \%$ to ensure the level of capital depending on the results of stress testing and taking into account the possible introduction of additional buffers).

As it can be seen from formula 3, the potential will arise in case of exceeding the regulatory (estimated) value of assets over the actual level. It should be noted that in case of insufficient level of equity, the profit will be used to increase capital, and possibilities of increasing the risk of assets associated with lending are limited. Therefore, we consider it necessary to add profit to the lending potential only under certain conditions:

$$
P_{\text {condfr }, i}=\left\{\begin{array}{c}
\max \left\{0 ; \text { fr } r_{i}\right\}, \text { if } P_{c, i}>0 \\
0 \text { in other cases }
\end{array}\right.
$$

where $\mathrm{P}_{c o n d f r, i}$ - profit, which can be used for lending in the absence of need for its capitalization; $f r_{i}$ - the value of the financial result of the bank $i$ in accordance with the reporting.

Taking into account all the limitations, the value of the lending potential of the banking system will be as follows: 


$$
L P_{b s}=\sum_{i=1}^{n} \min \left\{P_{l, i} ; P_{c, i}\right\}+P_{c o n d f r, i}
$$

The results of calculation of the lending potential of Ukrainian banks are presented in Fig. 1-7 [11]. The distribution of components of the lending potential of Ukrainian banks in 2013 is shown in Fig. 1.

40000000

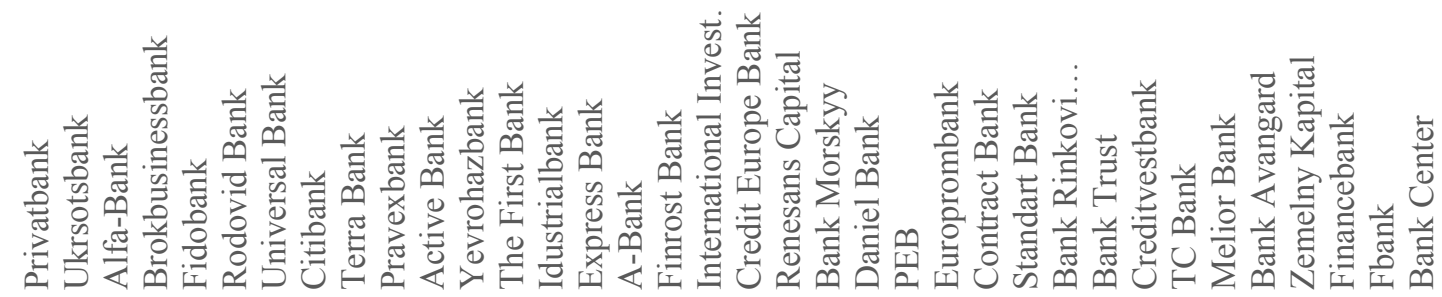

30000000

20000000

10000000

0

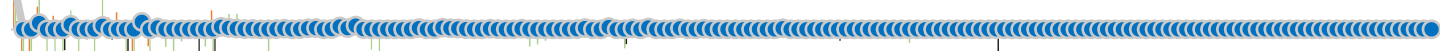

$-10000000$

$-20000000$

$-30000000$

$-40000000$

\begin{tabular}{lr} 
Liquidity & Capital adequacy \\
\hline Financial result & - Lending potential \\
\hline
\end{tabular}

Fig. 1. Components and values of lending potential of Ukrainian banks as of 01.01.2014, thousand UAH

Source: own design

The activity of the banking system of Ukraine in 2013 is characterized by insignificant lending potential, which is $1.8 \%$ of net assets. A positive contribution to the lending potential (above 1\%) is provided by the following banks: Privatbank, Delta Bank, Sberbank Rosiyi, Bank Finance and Credit, VAB Bank, Credit Agricole Bank, Khreshchatyk, Bank Kuivska Rus, Platinum Bank, Ukrbiznesbank, Aktabank, Diamantbank, Avant Bank and Ekspobank. The positive contribution to the potential of the system of small banks is made due to their profitable operation and low activity (large liquidity reserves and a high level of equity adequacy).

The components of the lending potential of Ukrainian banks in 2014 are shown in Fig. 2.

40000000

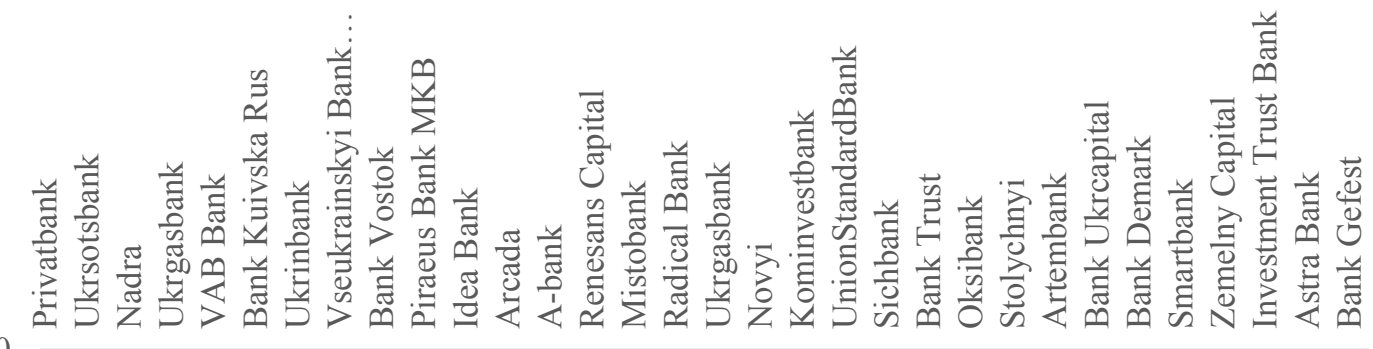

30000000

20000000

10000000

0

$-10000000$

$-20000000$

$-30000000$

$-40000000$

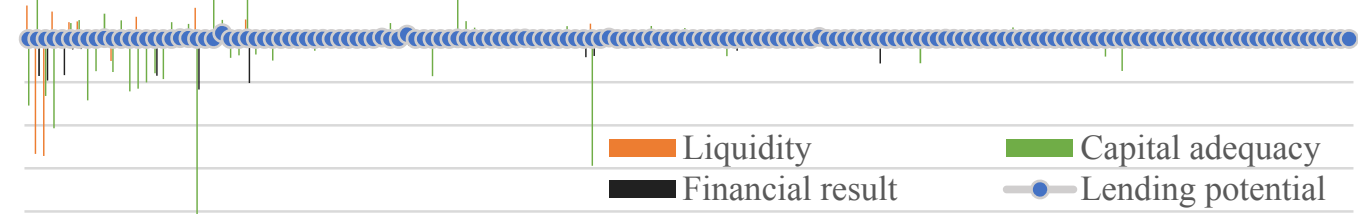

Fig. 2. Components and values of the lending potential of Ukrainian banks as of 01.01.2015, thousand UAH

Source: own design 
According to the data of Fig. 2, in 2014 and compared to the previous year, the number of banks with insufficient equity increased significantly; the level of lending potential was only $0.51 \%$ of net assets. The following banks made a positive contribution to the formation of lending potential: PJSC Derzhzembank, PJSC Ukrsotsbank, PJSC VS Bank, JSC Piraeus Bank MKB, PJSC ING Bank Ukraine, PJSC Citibank, PJSC Credit Europe Bank, PJSC Deutsche Bank DBU and some others.

It should be noted that there are no positive dynamics of both individual components and the total amount of lending potential of banks in 2015 (Fig. 3).

60000000

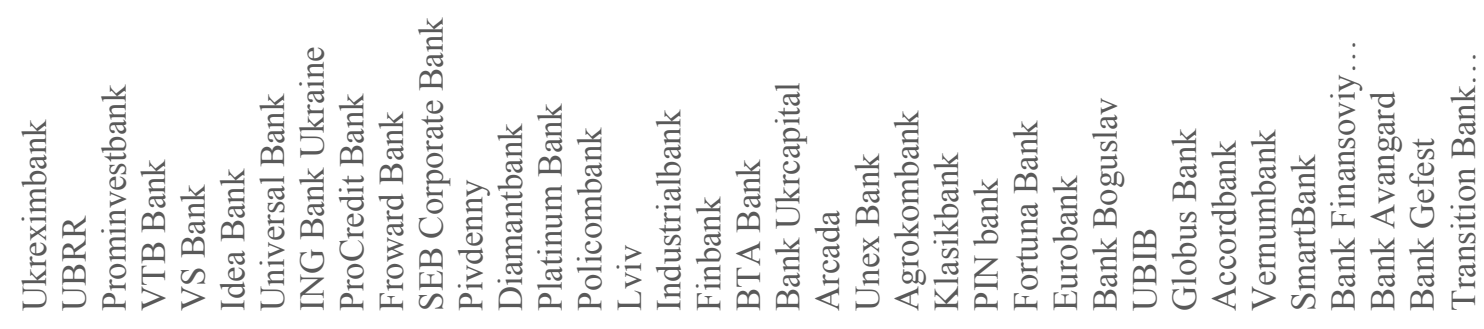

40000000

20000000

0

$-20000000$

$-40000000$

$-60000000$

$-80000000$

$-100000000$

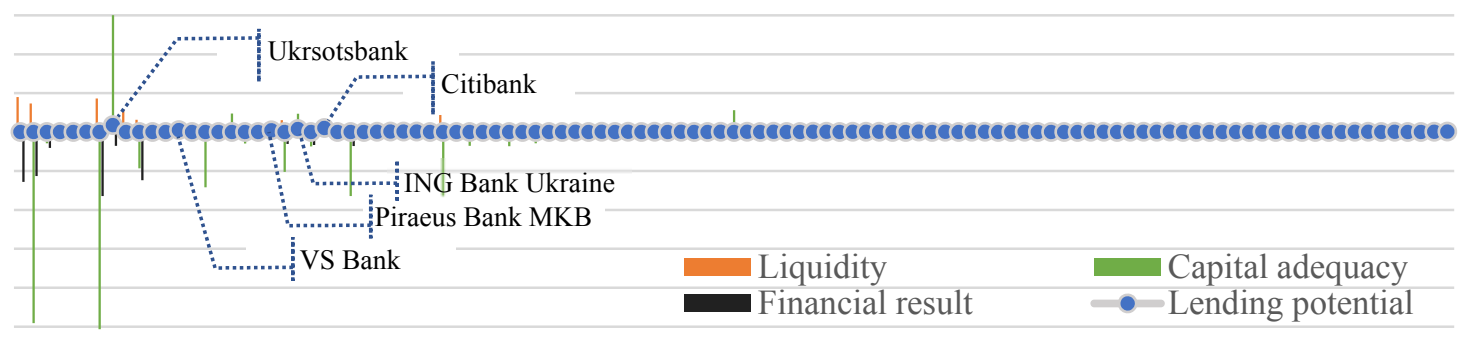

Fig. 3. Components and values of lending potential of Ukrainian banks as of 01.01.2016, thousand UAH

Source: own design

As of 01.01 .2016 , the value of the lending potential of the banking system of Ukraine is only $0.86 \%$ of net assets. It should be noted that the positive potential is provided by the results of operations of the following banks: PJSC Ukrsotsbank (33.54\%), PJSC VS Bank (8.36\%), JSC Piraeus Bank MKB (7.48\%), PJSC ING Bank Ukraine (13.45\%) and JSC Citibank (18.44\%). The contribution of such banks as: PJSC Crediteurope bank, PJSC Deutsche Bank DBU, PJSC SEB Corporate Bank, JSB Express Bank and PJSC Transition Bank "RwSbank" slightly exceeds $1 \%$ of the potential, some small banks make a small positive contribution to the lending potential of the system, but the contribution of a significant number of market leaders is zero primarily due to significant losses and insufficient capital amount.

To compare the distribution of components of the lending potential of Ukrainian banks in 2016 with previous periods allow the data of Fig. 4.

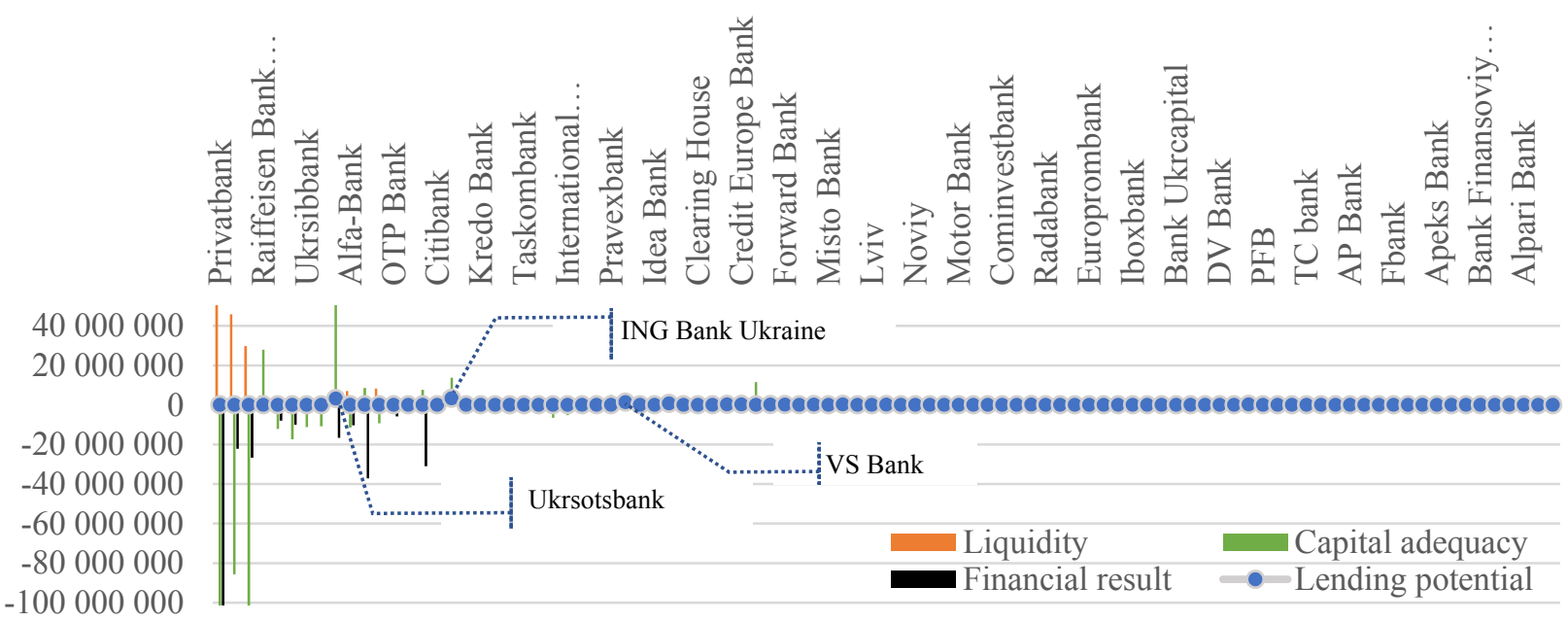

Fig.4. Components and values of lending potential of banks of Ukraine as of 01.01.2017, thousand UAH

Source: own design 
The configuration of the graph in Fig. 4 indicates a relative revival of banking activity, although it is too early to talk about the restoration of the positive dynamics of the lending potential of Ukrainian banks: in this period the value of lending potential was $0.87 \%$, which corresponds to the level of the previous period. The following banks make a significant contribution to the formation of the lending potential of the banking system of Ukraine in this period: PJSC Ukrsotsbank (7.67\%), PJSC ING Bank Ukraine (19.19\%) and PJSC VS Bank $(33.92 \%)$. The distribution of the components of the lending potential of Ukrainian banks in 2017 is shown in Fig. 5.

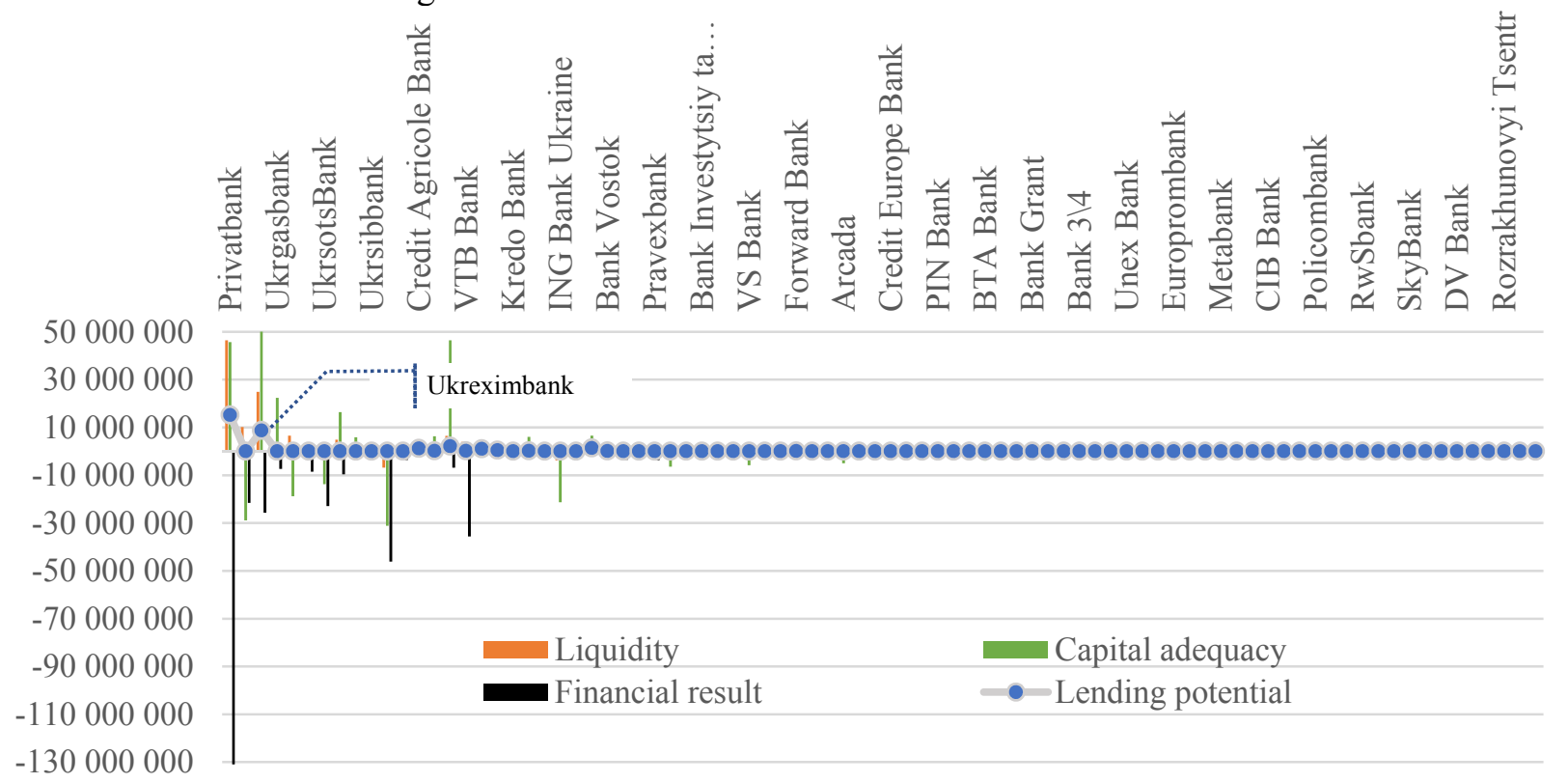

Fig. 5. Components and values of credit potential of banks of Ukraine as of 01.01.2018, thousand UAH Source: own design

According to the data presented in the figure, the lending potential of Ukrainian banks is gradually recovering: banks are gradually reducing the catastrophic losses incurred during 2013-2016, increasing equity and increasing liquidity reserves. The level of lending potential in this period is $2.3 \%$ of net assets despite the positive dynamics, the level of lending potential remains insignificant. It should be noted that significant amounts of lending potential are concentrated in state-owned banks: PJSC Privatbank (48.9\%) and JSC Ukreximbank (28.13\%).

The distribution of the components of the lending potential of Ukrainian banks in 2018 and the results of the 1st half of 2019 is shown in Fig. 6 and 7 respectively.
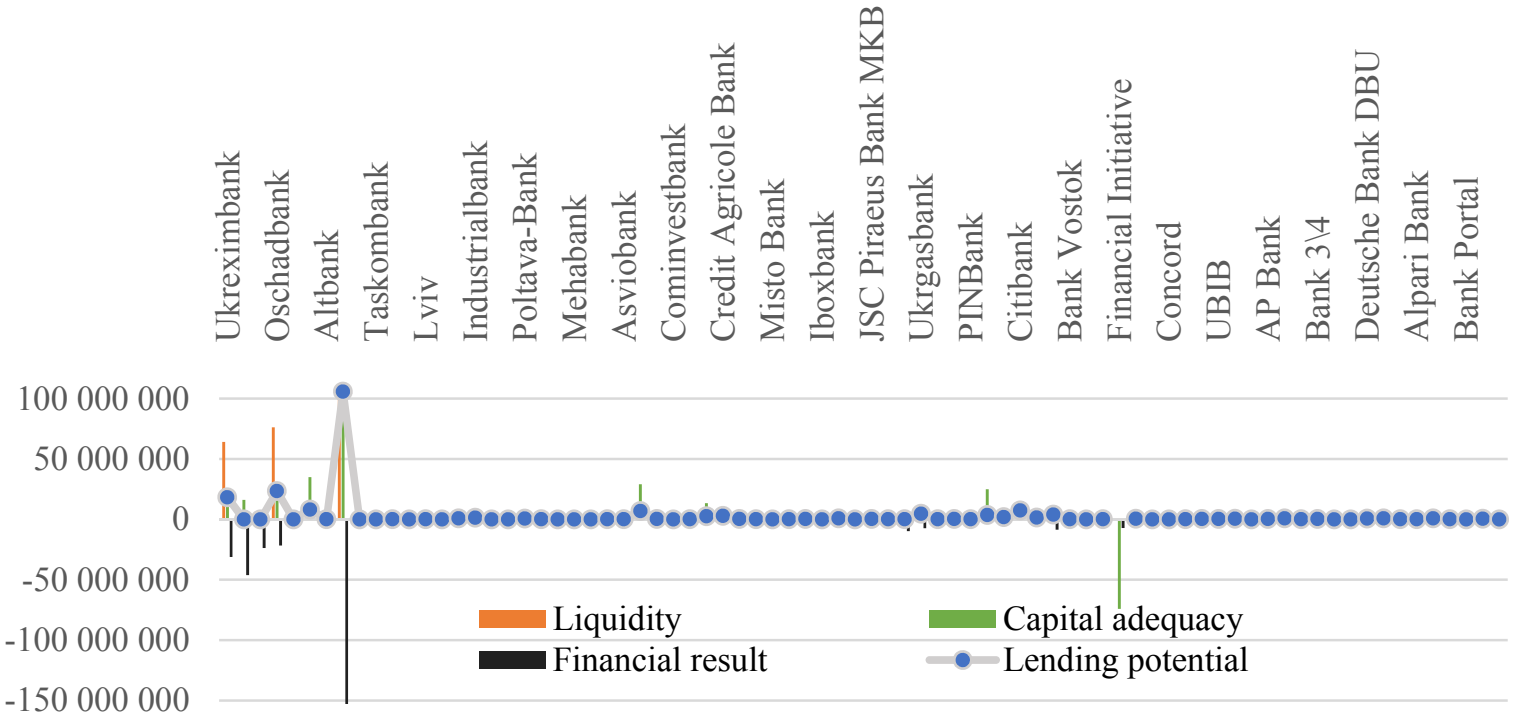

Fig. 6. Components and values of lending potential of banks of Ukraine as of 01.01.2019, thousand UAH

Source: own design 
According to Figs. 6 and 7 we can draw conclusions about the jump in the growth of lending potential of Ukrainian banks - this figure in 2018 amounted to $15.22 \%$, and in the 1st half of $2019-22.7 \%$ of net assets of banks. A comparison of the configurations of graphs 6 and 7 shows the preservation of a high level of lending potential of Ukrainian banks and the reduction of losses that had a negative impact on its value.

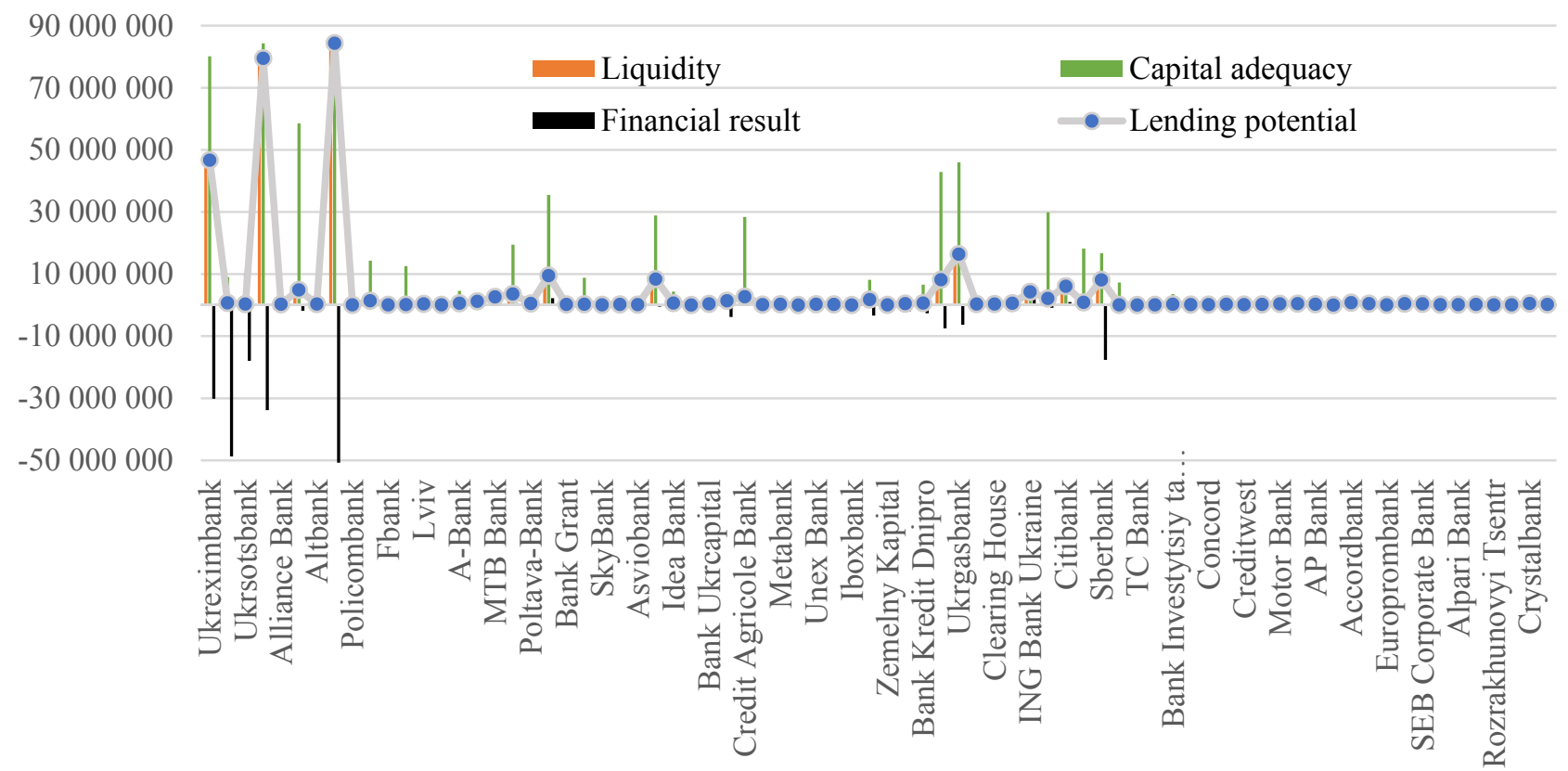

\section{Fig. 7. Components and values of lending potential of Ukrainian banks} as of July 1, 2019, thousand UAH

Source: own design

At the same time, it should be noted that the high level of lending potential of Ukrainian banks is formed, firstly, by reducing losses and restoring equity adequacy, and secondly, by a significant amount of liquidity reserves, which mainly consist of government securities. Therefore, the key to the growth of lending by banks to the real sector of economy is the reduction of investments in government securities and the resumption of corporate lending.

We can note that the availability of lending potential of the banking system is an essential but not sufficient condition for the resumption of lending and the implementation of such a role of banks as promoting economic development, including innovation. Also, the possibility of expanding the lending activities of banks is determined by the ability of borrowers to repay the debt in full and within the contractual period, determined by the level of its debt load.

Analysis of the scientific literature on financial management and lending assessment of real sector enterprises and non-financial companies [12, p. 213] allowed substantiating groups of indicators of debt load of borrowers that:

- are determined by the capital structure: the ratio of debt to equity, the share of long-term liabilities;

- are determined by the ratio of assets and liabilities: the ratio of long-term liabilities and non-current assets; the ratio of current assets and current liabilities;

- are determined by the adequacy of financial results to cover the cost of debt service: the ratio of operating income and financial expenses; ratio of EBIDTA and financial costs.

The first group of indicators includes the ratio of debt to equity. The dynamics of the components and the ratio of equity and liabilities of large and medium-sized enterprises of real sector of Ukraine are presented in Fig. 8.

We should note that the greater the value of financial leverage is, the higher the risk of company's bankruptcy is. The recommended values of the financial lever are in the range from 1 to 2.3. In fact, the stronger the indicator deviates from 1 in the direction of increase, the higher debt load is characteristic for the company.

The value of debt load indicators suggests the following:

- high level of debt load in enterprises in 2016-2017, which indicates the lack of prerequisites for the development of lending for innovation, both in banking and real sectors of the economy; 

level;

- the share of obligations in liabilities decreases, but its level remains high compared to the theoretical

- liabilities structure is irrational given the prevalence of current liabilities.



Fig. 8. Dynamics of components and indicators of debt load, determined by the capital structure of large and medium-sized enterprises of Ukraine in the period 2013-1 half of 2019 Source: compiled by the author according to the data [13] Fig. 9.

The dynamics of debt load indicators, determined by the ratio of assets and liabilities, is shown in

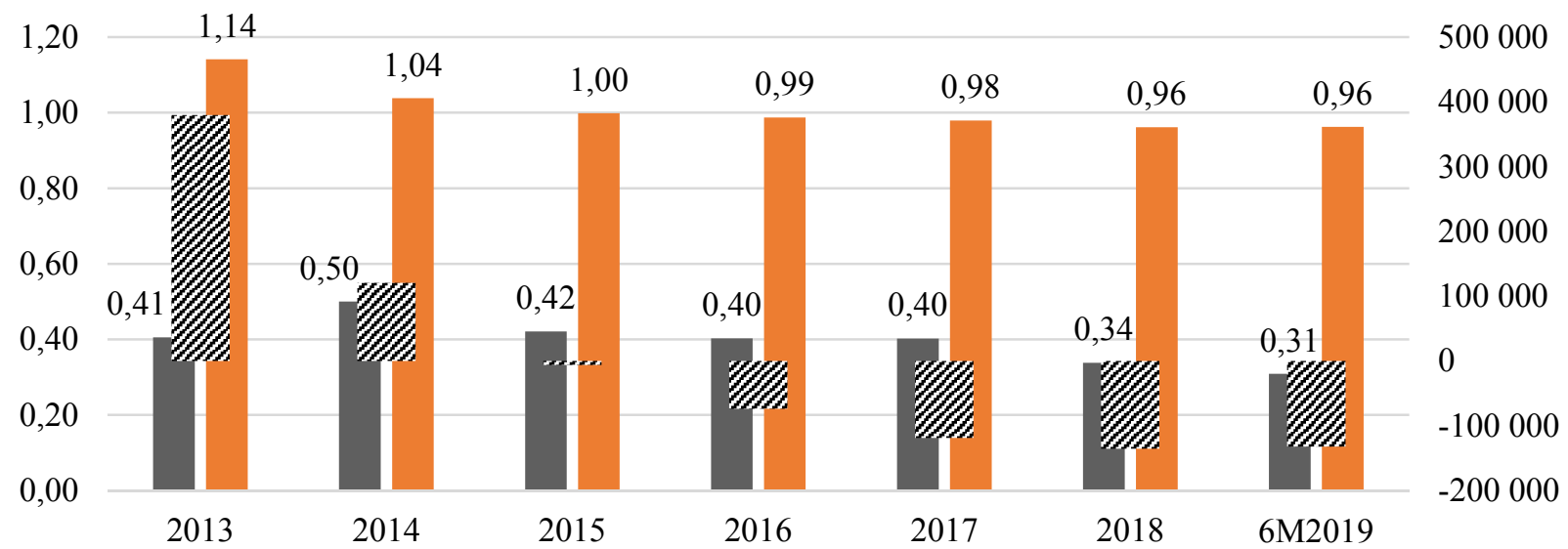

u Long-term liabilities / Non-current assets (ratio) $\square$ Working assets / Current liabilities (ratio)

$\approx$ Net working capital (right-scale), million UAH

Fig. 9. Dynamics of debt load indicators, which are determined by the ratio of assets and liabilities of large and medium-sized enterprises of Ukraine for the period 2013-1 half of 2019 Source: compiled by the author according to the data [13]

The dynamics of the ratio of assets and liabilities indicates that short-term loans are used to fund noncurrent assets, as evidenced by the negative net working capital. At the same time, the role of lending resources in financing fixed assets is decreasing, which creates prerequisites for the development of longterm lending. 
The data of Fig. 10 indicate the resumption of profitable activities of real sector enterprises: during the period under review, both operating profit and EBIDTA grew faster than the financial costs associated with debt service. Therefore, the ratio of profit and financial costs increases.

This ratio characterizes the protection degree of creditors from non-payment of interest on the loan and shows how many times during the reporting period the company has earned money to pay interest on loans. It also allows you to determine the allowable level of profit reduction used to pay interest. The norm is a value of more than 1 , which means that the company does not spend all its profits on interest. Thus, the level of this indicator demonstrates a reduction in the debt load on medium and large enterprises in Ukraine.

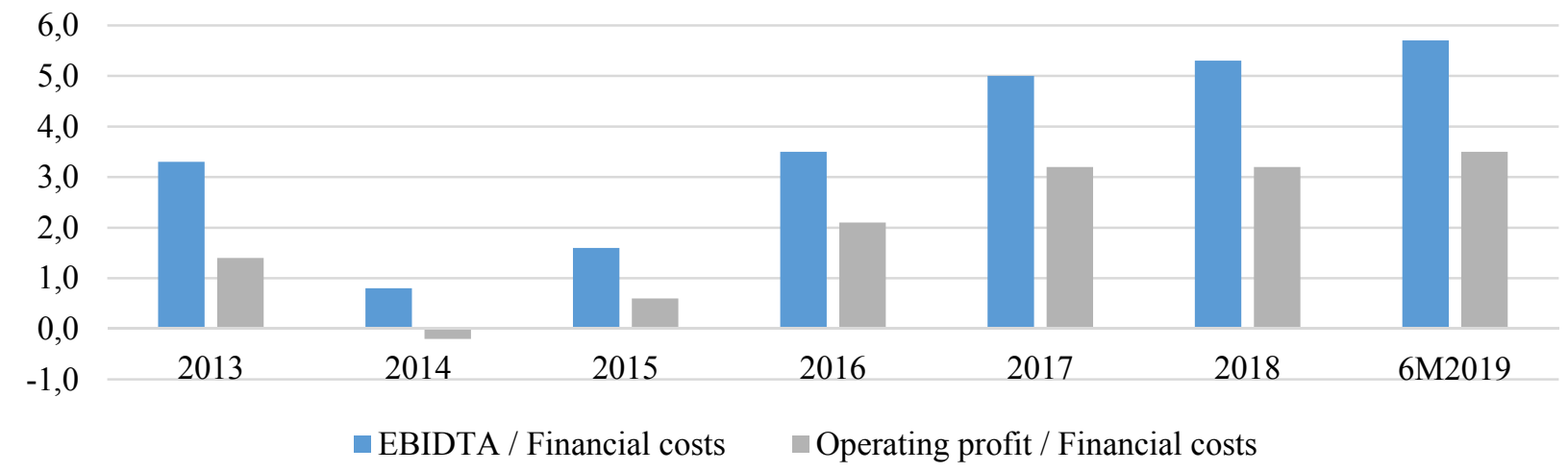

Fig. 10. Dynamics of indicators of adequacy of financial result for debt service of large and mediumsized enterprises of Ukraine for the period 2013-1 half of 2019

Source: compiled by the author according to the data [14]

It should be noted that the clarification of the conclusions requires a comparison of debt load by types of economic activity (Fig. 11-15).

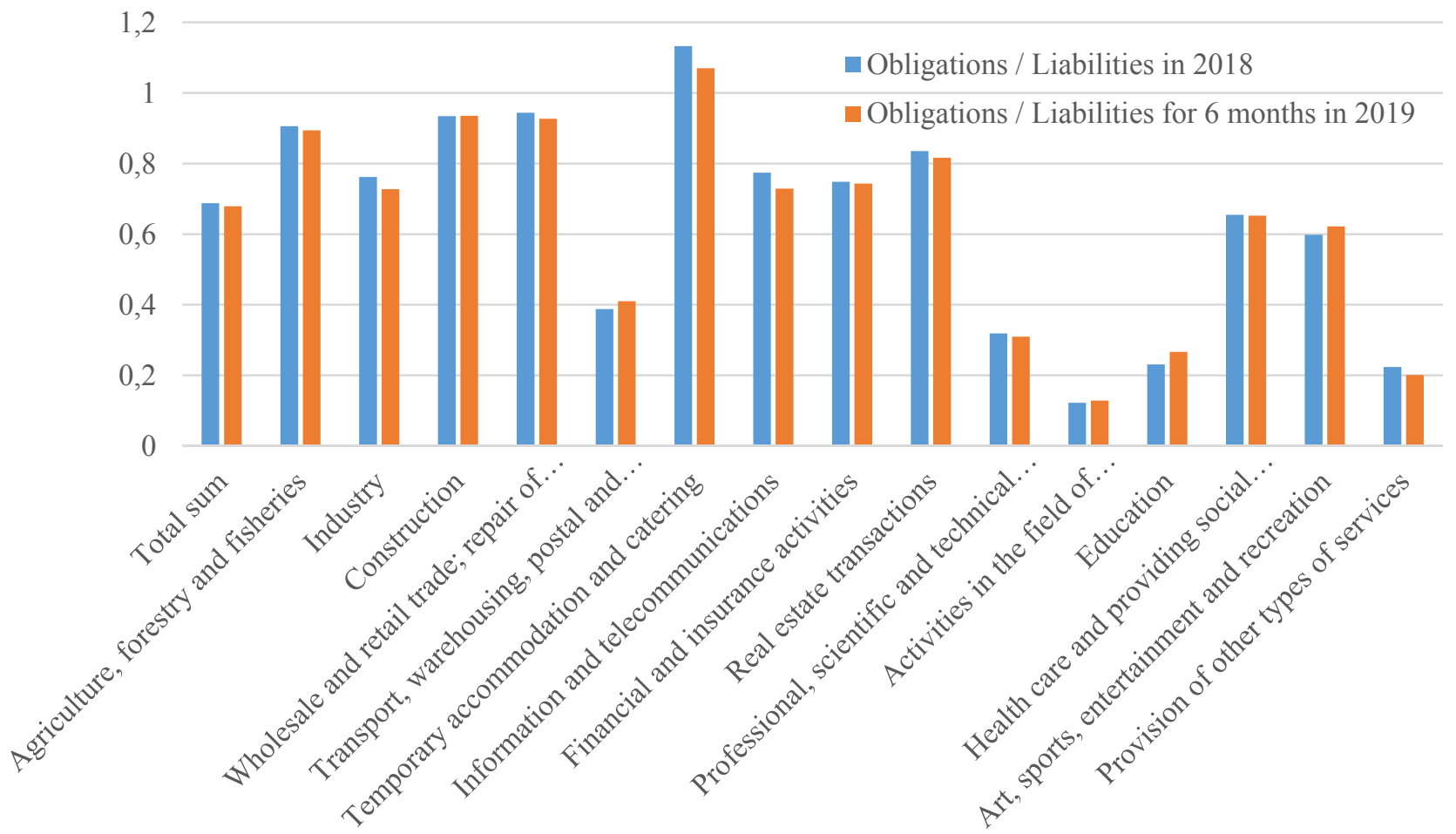

Fig. 11. Dynamics of the liabilities share in the liabilities of large and medium-sized enterprises of Ukraine for the period 2018-1 half of 2019 in terms of economic activities

Source: compiled according to the data [13] 
As the data of Fig. 6, most industries have an acceptable level of debt load. The most actively lending resources are used by such industries as agriculture, industry and trade, and real estate transactions.

The type of activity "temporary accommodation and catering" is unprofitable with a negative amount of equity, which is further confirmed by the data of Fig. 12.

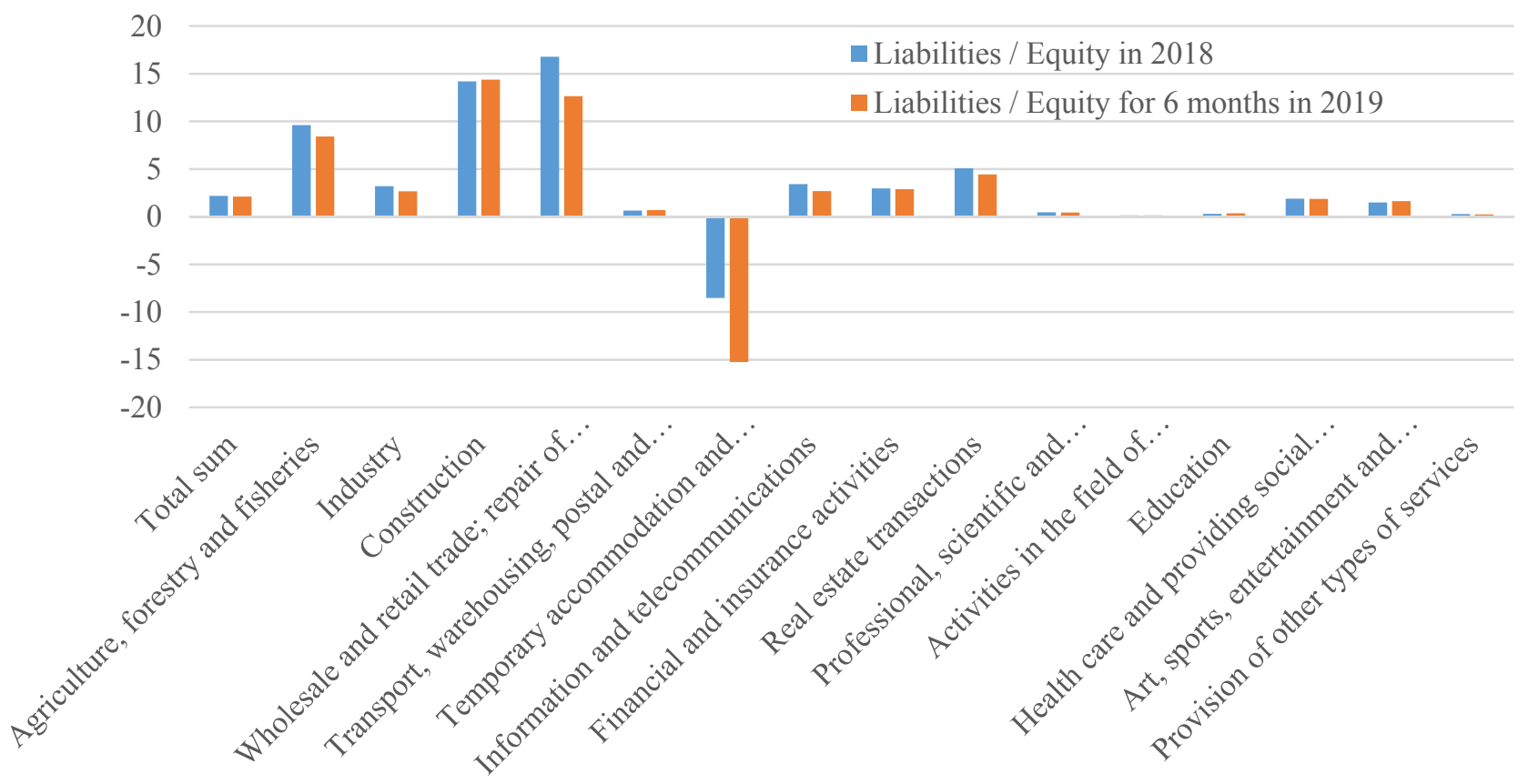

Fig. 12. Dynamics of the ratio of liabilities and equity of large and medium-sized enterprises of Ukraine for the period 2018-1 half of 2019 in terms of economic activities Source: compiled according to the data [13]

The sources of financing non-current assets by industries are shown in Fig. 13.

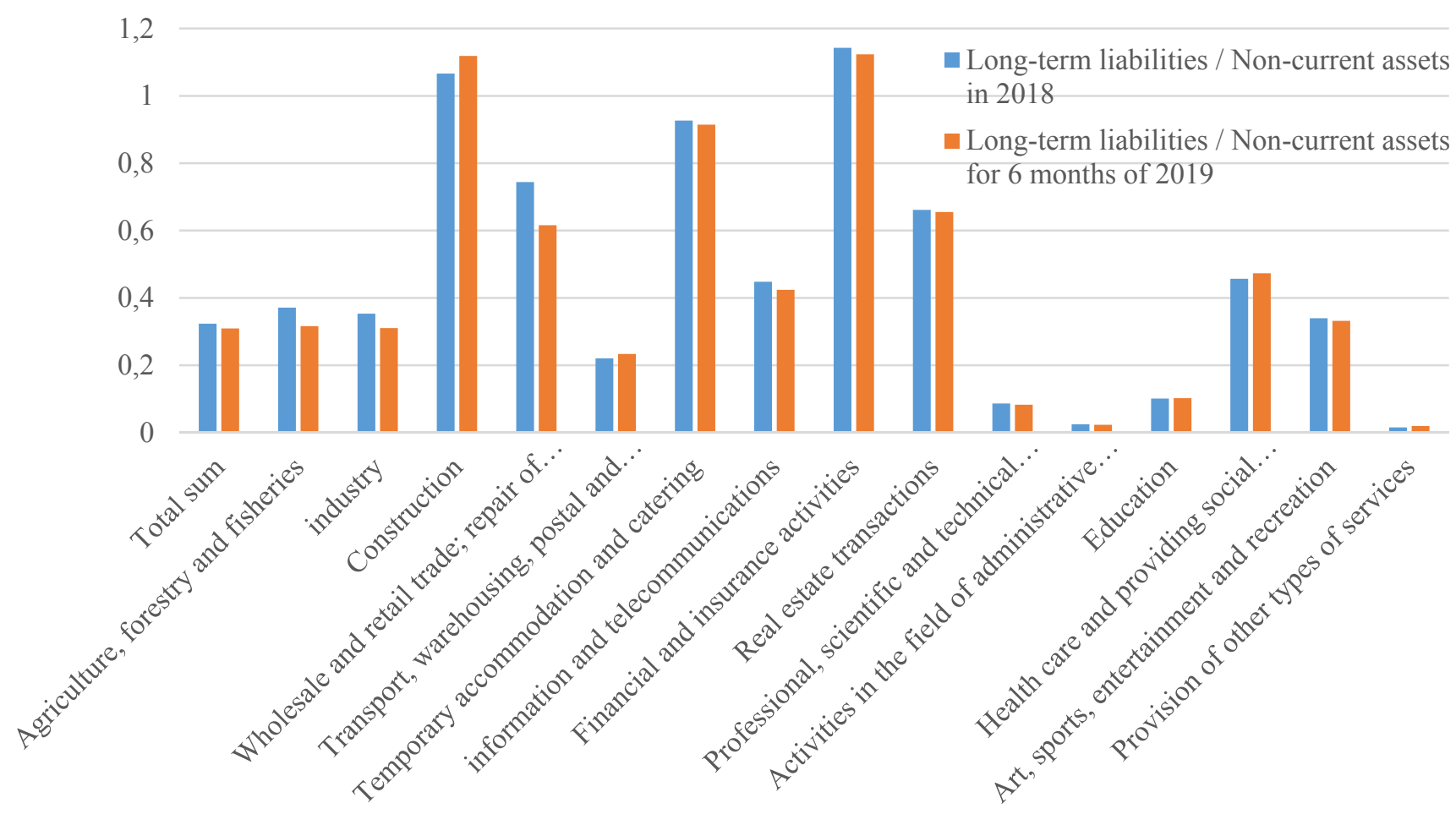

Fig. 13. Dynamics of the ratio of long-term liabilities and non-current assets of large and medium-sized enterprises of Ukraine for the period 2018-1 half of 2019 in terms of economic activities

Source: compiled by the author according to the data [13] 
The data of Fig. 13 indicate that in most industries to finance non-current assets short-term liabilities are used, as well. This situation indicates the creation of preconditions for long-term lending to the real sector of economy. According to the data of Fig. 14, for most industries the current liquidity ratio is less than 1 , which indicates a low level of their solvency.



Fig. 14. Dynamics of the ratio of current assets and current liabilities of large and medium-sized enterprises of Ukraine for the period 2018-1 half of 2019 in terms of economic activities Source: compiled by the author according to the data [13]

At the same time, the level of debt load is reduced if we analyze the indicators that are related to profit (Fig. 15).

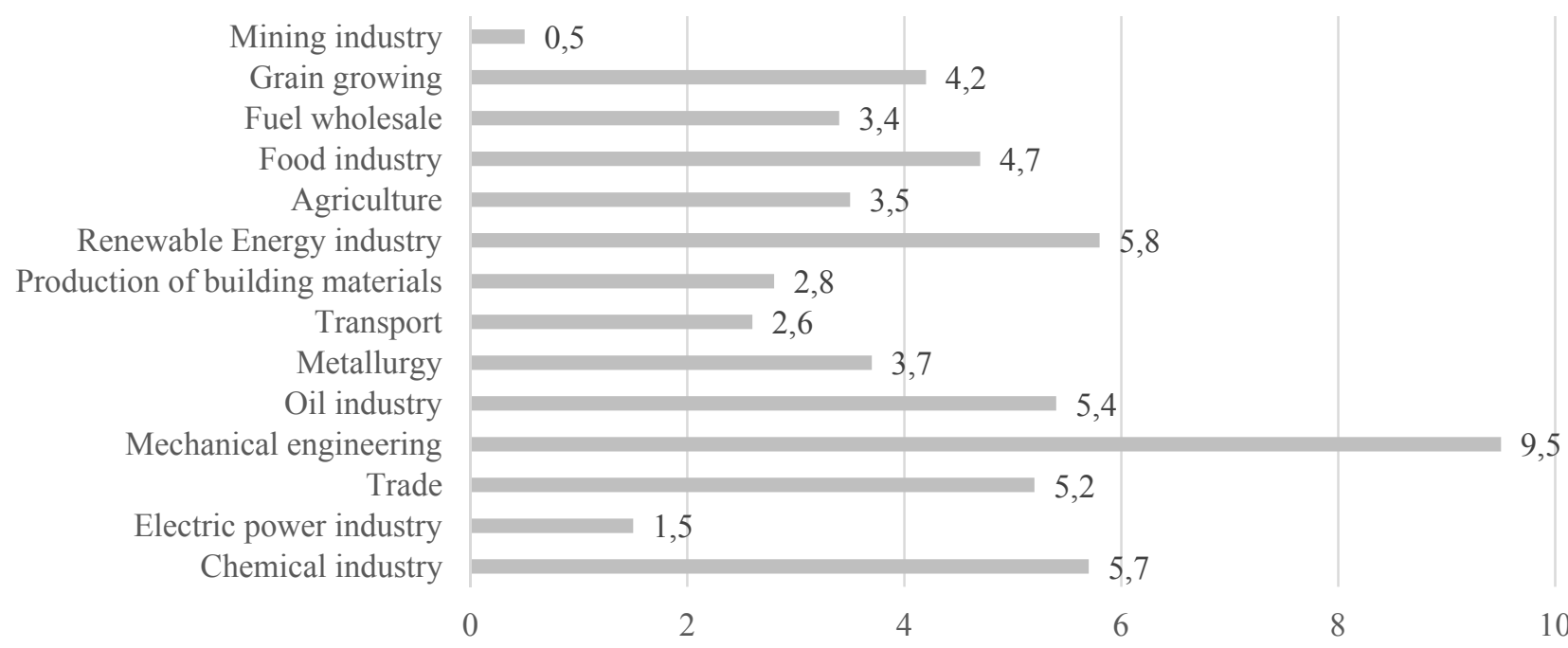

Fig. 15.The ratio of gross debt to EBITDA by industries in 2018

Source: compiled by the author according to the data [14]

The critical value for the ratio of gross debt to EBITDA is the level of 7 times. This level characterizes only the activities of the engineering industry; industries such as renewable energy and the food industry are also relatively high. In 2018, the debt load in mechanical engineering was high, 9.5: despite the overall positive dynamics in the industry, some subsectors were stagnating.

During the year, the profits of energy engineering companies decreased. Large enterprises in the industry have been able to partially reorient to new markets after the loss of the Russian market, but regular orders are lacking [14]. Trade traditionally uses significant leverage in operating activities. Banks lend to companies in the 
industry, relying on the liquidity of current assets and taking into account its high growth rate. However, it is advisable for banks to more carefully assess the risks of commercial enterprises, given the high level of defaults among them during past crises. Thus, enterprises in most industries have a sufficient margin of operating profit to cover the possible increase in the cost of lending. Exceptions are the energy sector, construction and some metallurgical enterprises. However, some large state-owned companies need additional funding to upgrade fixed assets or replenish working capital. External borrowing is too expensive, so sources of funding will have to be sought in the domestic market, especially in Ukrainian banks.

A comparison of the lending potential of banks and individual indicators of the debt load of enterprises allows us to draw conclusions about the formation of prerequisites for the development of bank lending (Fig. 16).

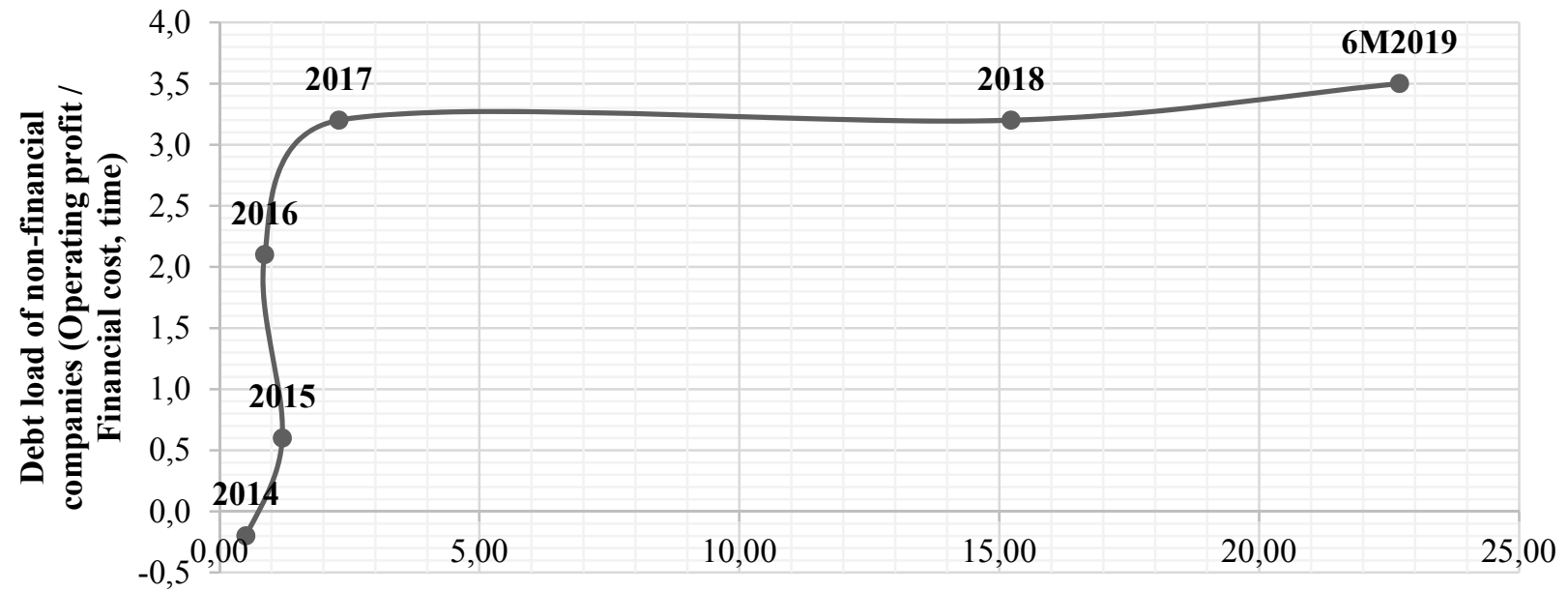

Lendinag potential of banks ( $\%$ / assets)

Fig. 16. Dynamics of lending potential of banks and debt load of non-financial companies of Ukraine for the period 2014-1 half of 2019

Source: own design

According to the results of the calculations insignificant lending potential of Ukrainian banks was revealed in 2014-2017, which is growing rapidly since 2018. The profitability of non-financial corporations is gradually increasing during the study period, which has a positive effect on their debt load service [12, p. 220]. These trends create the prerequisites for the development of bank lending to real sector of economy and households.

The above mentioned indicates the need to develop a number of measures for the rational use of this potential to achieve the objectives of innovative economic development, since current practice indicates the underdevelopment of banking products in the field of promoting innovative development (Table 1).

Table 1

Services of Ukrainian banks in the project financing market

\begin{tabular}{|c|c|c|c|}
\hline \multirow[b]{2}{*}{ Banks } & \multicolumn{2}{|l|}{ Services } & \multirow[b]{2}{*}{$\begin{array}{c}\text { Share in } \\
\text { lending } \\
\text { potential } \\
\text { as of July 1, } \\
2019\end{array}$} \\
\hline & Project financing & $\begin{array}{c}\text { Investment } \\
\text { financing in a } \\
\text { form other than } \\
\text { project } \\
\text { financing }\end{array}$ & \\
\hline 1 & 2 & 3 & 4 \\
\hline JSC Ukrsibbank & $\begin{array}{l}\text { project financing for the following projects: } \\
\text { construction / reconstruction of commercial and } \\
\text { residential real estate; production, modernization of } \\
\text { production lines (technological projects) mergers }\end{array}$ & $\begin{array}{l}\text { Does not carry } \\
\text { out }\end{array}$ & $2.72 \%$ \\
\hline JSC Alfa-Bank & $\begin{array}{l}\text { and acquisitions (acquisition of companies, } \\
\text { integrated housing complexes and businesses); } \\
\text { infrastructure (roads, telecommunications, etc.) }\end{array}$ & $\begin{array}{l}\text { Loan for } \\
\text { investment needs }\end{array}$ & $2.65 \%$ \\
\hline
\end{tabular}


Continuation of the table 1

\begin{tabular}{|c|c|c|c|}
\hline & & & \\
\hline 1 & 2 & 3 & 4 \\
\hline OTP Bank JSC & $\begin{array}{l}\text { Non-Recourse Project financing } \\
\text { Limited Recourse Project financing } \\
\text { Financing is provided in the form of a loan or a } \\
\text { combination of a term loan and a revolving lending } \\
\text { line to finance the costs of launching the project and } \\
\text { replenishing working capital }\end{array}$ & $\begin{array}{lr}\text { Loan } & \text { for } \\
\text { investment needs }\end{array}$ & $0.67 \%$ \\
\hline JSC Ukreximbank & $\begin{array}{l}\text { modernization or reconstruction of existing } \\
\text { production (provision of services), organization of } \\
\text { production of new products (provision of services), }\end{array}$ & Loan & $15.12 \%$ \\
\hline JSC Sberbank & $\begin{array}{l}\text { comprehensive financing of long-term investment } \\
\text { projects to achieve the strategic goals of the } \\
\text { company }\end{array}$ & investment needs & $2.63 \%$ \\
\hline $\begin{array}{l}\text { Raiffeisen Bank Aval } \\
\text { JSC }\end{array}$ & $\begin{array}{l}\text { modernization or reconstruction of existing } \\
\text { production (provision of services), organization of } \\
\text { production of new products (provision of services), } \\
\text { comprehensive financing of long-term investment } \\
\text { projects to achieve the strategic goals of the } \\
\text { company }\end{array}$ & $\begin{array}{lr}\text { Loan } & \text { for } \\
\text { investment needs }\end{array}$ & $1.59 \%$ \\
\hline
\end{tabular}

Source: compiled by the author according to the data [12, p. 222]

We should note that capital-intensive infrastructure projects for the construction of solar and wind power plants, warehouses, recycling facilities, biogas plants, grain terminals, etc. are funded using debt financing instruments, participation in the capital of sponsors, international financial institutions and export lending agencies [15]. According to the State Statistics Committee [13], only 6\% of innovative projects are financed with bank loans. From which we can conclude about the insignificant level of development of banking segment of the project financing market in Ukraine, which is due to macroeconomic factors and the banks' own interests.

According to the Table 2, a significant share of the banks' loan portfolio is directed to short- and medium-term loans for non-financial corporations, which in the $1^{\text {st }}$ half of 2019 amounted to $81.3 \%$. However, the development of bank project financing requires long-term investment of resources, which in the structure of banks' lending investments account for only $18.1 \%$.

Table 2

Dynamics of loans granted by banks to non-financial corporations in terms of 2012-1 half of 2019

\begin{tabular}{|c|c|c|c|c|c|c|c|c|c|c|}
\hline \multirow[b]{3}{*}{ Indicators } & \multicolumn{10}{|c|}{ As of 31.12: } \\
\hline & \multicolumn{2}{|c|}{2012} & \multicolumn{2}{|c|}{2014} & \multicolumn{2}{|c|}{2016} & \multicolumn{2}{|c|}{2018} & \multicolumn{2}{|c|}{6 months of 2019} \\
\hline & 高咅 & $\begin{array}{l}\stackrel{5}{\frac{\pi}{0}} \\
\frac{0}{0} \\
0\end{array}$ & 言 & $\frac{\sqrt[5]{5}}{\stackrel{5}{0}}$ & 言 & 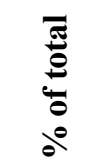 & 高 & $\begin{array}{l}\frac{5}{5} \\
\stackrel{5}{0} \\
0 \\
0\end{array}$ & 高害 & 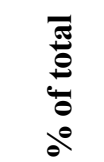 \\
\hline Up to 1 year & 296.5 & 48.9 & 339.6 & 43.6 & 306.0 & 37.2 & 413.6 & 48.1 & 396.4 & 49.0 \\
\hline $1-5$ years & 235.1 & 38.8 & 333.6 & 42.8 & 353.7 & 43.0 & 278.1 & 32.3 & 261.1 & 32.3 \\
\hline More than 5 years & 798.3 & 13.1 & 105.5 & 13.5 & 162.3 & 19.7 & 167.9 & 19.5 & 147.0 & 18.1 \\
\hline Total: & 605.4 & 100.0 & 778.8 & 100.0 & 822.1 & 100.0 & 859.7 & 100.0 & 808.2 & 100.0 \\
\hline $\begin{array}{l}\text { Including loans for } \\
\text { purchase, } \\
\text { construction and } \\
\text { reconstruction of } \\
\text { real estate }\end{array}$ & 7.4 & 1.2 & 15.5 & 2.0 & 11.1 & 1.3 & 33.5 & 3.9 & 23.1 & 2.8 \\
\hline Up to 1 year & 1.1 & 0.2 & 1.0 & 0.1 & 2.1 & 0.2 & 2.5 & 0.2 & 2.6 & 0.3 \\
\hline $1-5$ years & 2.6 & 0.4 & 6.9 & 0.8 & 4.2 & 0.5 & 9.7 & 1.1 & 5.6 & 0.6 \\
\hline More than 5 years & 3.6 & 0.6 & 7.5 & 0.9 & 4.7 & 0.5 & 21.3 & 2.4 & 14.8 & 1.8 \\
\hline
\end{tabular}

Source: compiled by the author according to the data [11]

The insignificant role of banks in financing investment projects is evidenced by the share of loans for the purchase, construction and reconstruction of real estate, which is $2.8 \%$ in the 1 st half of 2019 against $7.4 \%$ in 
2012. On the other hand, lending by banks to innovative projects of enterprises of real sector of economy is limited by the ability to provide long-term loans due to strict lending risk assessment procedures and lack of long-term lending resources.

Most of the money accumulated by the banking sector (88.0\%) is short-term, determining the direction of bank loans for short-term financial investments (Table 3).

Table 3

Dynamics of deposits in terms of 2012-1 half of 2019

\begin{tabular}{|c|c|c|c|c|c|c|c|c|c|c|}
\hline \multirow[b]{3}{*}{ Indicators } & \multicolumn{10}{|c|}{ As of 31.12: } \\
\hline & \multicolumn{2}{|c|}{2012} & \multicolumn{2}{|c|}{2014} & \multicolumn{2}{|c|}{2012} & \multicolumn{2}{|c|}{2018} & \multicolumn{2}{|c|}{2012} \\
\hline & 兰 & $\begin{array}{l}\frac{\pi}{0} \\
\frac{0}{0} \\
\frac{0}{0} \\
0^{\circ}\end{array}$ & 总 & 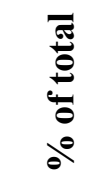 & 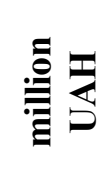 & $\begin{array}{l}\frac{\pi}{0} \\
\frac{\pi}{0} \\
\frac{0}{0} \\
0\end{array}$ & 毵 & $\begin{array}{l}\frac{\pi}{0} \\
\frac{\pi}{0} \\
\frac{0}{0}\end{array}$ & 高 & 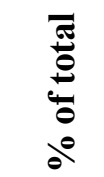 \\
\hline On request & 185.3 & 32.3 & 250.1 & 37.0 & 364.5 & 45.94 & 456.4 & 48.9 & 480.6 & 51.7 \\
\hline Up to 1 year & 187.9 & 32.8 & 210.4 & 31.1 & 271.8 & 34.26 & 322.0 & 34.5 & 341.6 & 36.3 \\
\hline $1-2$ years & 163.8 & 28.6 & 186.5 & 27.6 & 148.4 & 18.71 & 125.5 & 13.4 & 106.8 & 11.3 \\
\hline $\begin{array}{l}\text { More than } 2 \\
\text { years }\end{array}$ & 35.2 & 6.1 & 27.9 & 4.1 & 8.5 & 1.08 & 28.8 & 3.0 & 28.4 & 3.0 \\
\hline Total: & 572.3 & 100.0 & 675.0 & 100.0 & 793.4 & 100.0 & 932.9 & 100.0 & 939.2 & 100.0 \\
\hline
\end{tabular}

Source: compiled by the author according to the data [11]

We should note that the absolute amount of credit and deposit imbalance, as the difference between the volume of deposits for more than 2 years and lending for more than 5 years, according to the NBU, in the $1^{\text {st }}$ half of 2019 amounted to - 118.6 million UAH (the share of underfunded loans is $80.6 \%$ ), which has a negative impact on the formation of the lending potential of banking system at the level required to finance long-term innovation projects.

\section{Conclusions and prospects for further development of this area.}

1. Current achievements in terms of methodological approaches to assessing the lending potential of banks are summarized. From which the following conclusion is made that:

- lending potential of banks, according to the author's interpretation of the approach to its quantification, is the amount of excess liquidity or capital that arises when the relevant economic standards exceed the established level, and of profits that can be used for lending;

- differences from existing approaches are as follows: firstly, lending potential is defined as a possible increase in loans, rather than the entire result of lending activities; secondly, the quantitative assessment of potential is based on banks' compliance with economic standards and takes into account a number of limitations. The use of the proposed methodology allows assessing the prerequisites for the development of bank lending and the implementation of a positive contribution of banking system to economic growth.

2. According to the results of calculations of the lending potential of banks and some indicators of the debt load of enterprises it was revealed that:

- insignificant lending potential of Ukrainian banks in the period 2014-2017 is growing rapidly since 2018. The profitability of non-financial corporations is gradually increasing during the study period, which has a positive effect on their debt load services. These trends create the prerequisites for the development of bank lending to real sector of economy and households.

3. The insignificant level of development of banking segment of the project financing market in Ukraine was determined, namely:

- as of July 1, 2019, only 6 banks in Ukraine provided project financing services as forms of financing investment projects of clients, including: Raiffeisen Bank Aval JSC, JSC Ukrsibbank, JSC Ukreximbank, JSC Alfa-Bank, JSC Sberbank, JSC OTP Bank;

- loans granted by banks to non-financial corporations with a term of more than 5 years in the structure of lending investments of banks account for $18.1 \%$; deposits attracted by the banking sector for less than 2 years account for $88.0 \%$ of all accumulated funds, which indicates the short-term nature of the formation of the resource base; the share of underfunded loans, defined as the absolute amount of credit and deposit imbalance, is $80.6 \%$; 
- among the main factors hindering the development of bank project financing in Ukraine are the low level of public confidence in the banking system, unfavorable investment climate, restrictions of the National Bank of Ukraine for long-term financial investments and inefficient use of lending resources.

4. Based on the above mentioned, it is necessary to develop recommendations aimed at government incentives to intensify bank innovative lending:

- exemption from taxation of bank profits received from innovative lending to borrowers;

- reduction of the current tax rate in relation to the profit of banks, obtained as a result of innovative lending;

- granting banks the right to include the value of the mortgaged property (property rights) of the borrower in the calculation of the amount of the reserve to reimburse possible losses on innovative loans in the amount of not less than $50 \%$ of the market value of collateral;

- exemption from taxation of banks' profits resulting from lending to innovative projects of strategic importance to the state;

- reduction of the norm of obligatory reservation of resources involved for a period of one year. This will contribute to the formation of financial resources in the amounts and terms required for the implementation of lending to the needs of innovative activities of the corporate sector; reducing the cost of such loans for borrowers; increasing the level of innovation activity in the country.

Prospects for further development in this area of research are the development of measures for rational use of lending potential of banking system to achieve the objectives for ensuring innovation development of Ukraine's economy.

\section{Лimepamypa}

1. Доценко I. О. Сутність та значення кредитної діяльності банку у сучасних умовах економічного розвитку. Науковий вісник Ужгородського національного університету. 2017. Вип. 12. Ч. 1. С. $94-98$.

2. Шаповалова В. О. Аналіз кредитного потенціалу комерційного банку на базі когнітивного моделювання. Вісник Запорізького національного університету. 2016. № 1 (29). С. 60-66.

3. Букато В. И., Львов Ю. И., Головин Ю. В. Банки и банковские операции в России. Москва : Финансы и статистика, 2015. 234 с.

4. Tran D. V. Funding liquidity and bank lending. Cogent Economics \& Finance. 2020. Vol. 8. Issue 1. DOI: https://doi.org/10.1080/23322039.2020.1734324.

5. Polizzi S., Scannella E., Suárez N. The Role of Capital and Liquidity in Bank Lending : Are Banks Safer? Global Policy. 2020. Vol. 11. Issue 1. Pp. 28-38. DOI: https://doi.org/10.1111/1758-5899.12750.

6. Spatareanu M., Manole V., Kabiri A. Do bank liquidity shocks hamper firms' innovation? International Journal of Industrial Organization. 2019. Vol. 67. DOI: https://doi.org/10.1016/ j.ijindorg.2019.06.002.

7. Dahir A. M., Mahat F., Razak N. H. A., Bany-Ariffin A. N. Capital, funding liquidity, and bank lending in emerging economies: An application of the LSDVC approach. Borsa Istanbul Review. 2019. Vol. 19-2. Pp. 139-148. URL: http://www.elsevier.com/journals/borsa-istanbul-review/2214-8450 (accessed 19 December 2019).

8. Деменков А. В. Кредитный портфель коммерческого банка: природа возникновения и совершенствование методов управления. Электронный научный журнал «Вектор экономики». 2019. № 5. URL: http://www.vectoreconomy.ru/images/publications/2019/5/financeandcredit/Demenkov.pdf (дата обращения: 25.12.2019).

9. Потенціал / Словник української мови. Академічний тлумачний словник (1970-1980). URL: http://sum.in.ua/s/potencial (дата звернення: 17.12.2019).

10. Про визначення банками України розміру кредитного ризику за активними банківськими операціями : Постанова Правління НБУ № 351 від 30.06.2016. URL: https://zakon5.rada.gov.ua/ laws/show/v0351500-16/page (дата звернення: 23.12.2019).

29.12.2019).

11. Національний банк України : сайт. URL: https://www.bank.gov.ua (дата звернення:

12. Завадська Д. В. Банки у фінансуванні інноваційного розвитку економіки: дис. ... докт. екон. наук : 08.00.08. Одеса, 2019. 629 с.

13. Державна служба статистики України : сайт. URL: http://www.ukrstat.gov.ua (дата звернення: 05.01.2020). 
14. Звіт про фінансову стабільність (2019). Національний банк України, 50 с. URL: https://bank.gov.ua/news/all/zvit-pro-finansovu-stabilnist-cherven-2019-roku (дата звернення: 23.12.2019).

15. Project finance in Ukraine: Overview (2018) / Thomson Reuters. PRACTICAL LAW : website. URL: $\quad$ https://uk.practicallaw.thomsonreuters.com/7-636-4707?transitionType=Default\&contextData= (sc. Default)\& bhcp=1 (accessed 27 December 2019).

\section{References}

1. Dotsenko, I. O. (2017). Sutnist ta znachennia kredytnoi diialnosti banku u suchasnykh umovakh ekonomichnoho rozvytku [The essence and significance of lending activity of the bank in current conditions of economic development]. Naukovyi visnyk Uzhhorodskoho natsionalnoho universytetu - Scientific Bulletin of Uzhhorod National University, 12 (1), 94-98 [in Ukrainian]

2. Shapovalova, V. O. (2016). Analiz kredytnoho potentsialu komertsiinoho banku na bazi kohnityvnoho modeliuvannia [Analysis of lending potential of a commercial bank on the basis of cognitive modeling]. Visnyk Zaporizkoho natsionalnoho universytetu - Bulletin of Zaporizhia National University, 1 (29), 60-66 [in Ukrainian]

3. Bukato, V. I., Lvov, Yu. I. \& Golovin, Yu. V. (2015). Banki i bankovskie operatsii v Rossii [Banks and banking operations in Russia]. Moskva: Finansy i statistika, 234 s. [in Ukrainian]

4. Tran, D. V. (2020). Funding liquidity and bank lending. Cogent Economics \& Finance, 8 (1). DOI: https://doi.org/10.1080/23322039.2020.1734324

5. Polizzi, S., Scannella E. \& Suárez, N. (2020). The Role of Capital and Liquidity in Bank Lending: Are Banks Safer? Global Policy, 11 (1), 28-38. DOI: https://doi.org/10.1111/1758-5899.12750.

6. Spatareanu, M., Vlad Manole V. \& Kabiri, A. (2019). Do bank liquidity shocks hamper firms' innovation? International Journal of Industrial Organization, 67, 102520. DOI: https://doi.org/10.1016/ j.ijindorg.2019.06.002.

7. Dahir, A. M., Mahat, F., Razak, N. H. A. \& Bany-Ariffin A. N. (2019). Capital, funding liquidity, and bank lending in emerging economies: An application of the LSDVC approach. Borsa Istanbul Review, 19-2, 139-148. Retrieved from: http://www.elsevier.com/journals/borsa-istanbul-review/2214-8450 (accessed 19 December 2019).

8. Demenkov, A. V. (2019). Kreditnyy portfel kommercheskogo banka: priroda vozniknoveniya i sovershenstvovanie metodov upravleniya [Commercial bank loan portfolio: the nature of emergence and improvement of management methods]. Elektronnyy nauchnyy zhurnal «Vektor ekonomiki» - Electronic scientific journal «Vector of Economics», 5. Retrieved from: http://www.vectoreconomy.ru/images/ publications/2019/5/financeandcredit/Demenkov.pdf (accessed 25 December 2019) [in Russian]

9. Slovnyk ukrainskoi movy. Akademichnyi tlumachnyi slovnyk (1970-1980) [Dictionary of the Ukrainian language. Academic explanatory dictionary (1970-1980)]. Retrieved from: http://sum.in.ua/s/potencial (accessed 17 December 2019) [in Ukrainian]

10. Pro vyznachennia bankamy Ukrainy rozmiru kredytnoho ryzyku za aktyvnymy bankivskymy operatsiiamy: Postanova Pravlinnia NBU, No. 351, 30.06.2016 [On determining by banks the amount of lending risk of active banking operations: Law of Ukraine, No. 351, 30.06.2016]. Retrieved from: https://zakon5.rada.gov.ua/laws/show/v0351500-16/page (accessed 23 December 2019) [in Ukrainian]

11. Natsionalnyi bank Ukrainy : sait [National Bank of Ukraine: site]. Retrieved from: https://www.bank.gov.ua (accessed 29 December 2019) [in Ukrainian]

12. Zavadska, D. V. (2019). Banky u finansuvanni innovatsiinoho rozvytku ekonomiky: dysertatsiia dokt. ekon. nauk [Banks in Financing Innovative Development of Economy: doctoral thesis] Odesa, 629 s. [in Ukrainian]

13. Derzhavna sluzhba statystyky Ukrainy: sait [State Statistics Service of Ukraine: site]. Retrieved from: http://www.ukrstat.gov.ua (accessed 05 January 2020) [in Ukrainian]

14. Zvit pro finansovu stabilnist (2019) [Financial Stability Report], Kyiv: Natsionalnyi bank Ukrainy, 50 s. Retrieved from: https://bank.gov.ua/news/all/zvit-pro-finansovu-stabilnist-cherven-2019-roku (accessed 23 December 2019) [in Ukrainian]

15. Project finance in Ukraine: Overview (2018). Thomson Reuters. PRACTICAL LAW : website. Retrieved from: https://uk.practicallaw.thomsonreuters.com/7-636-4707?transitionType=Default\& contextData $=($ sc. Default $) \&$ bhcp=1 (accessed 27 December 2019). 